spoken. But whereas in Norway the entrance of foreign words is not resented, in Iceland they invariably undergo translation before acceptance. The writer was given to understand that the language is written and spoken in almost exactly the same manner as it was a thousand years ago, and that the ancient sagas can be read with the same ease as the modern newspaper. Probably there is no other country in Europe where this strange perpetuation of ancient forms of speech prevails.

\title{
The Survey of India.
}

THE report by Col. Ryder, the present SurveyorGeneral of India, referred to below, ${ }^{\mathbf{1}}$ shows that in the year 1919-20 the Indian Survey Department had fully recovered from the dislocation due to the War.

During this period there were no less than I9 survey parties in the field, of which 12 were topographical. On the normal scale of one inch per mile (much of which was revision) and smaller geographical scales, about 2800 square miles was turned out, while on the larger scales, ranging from $\mathrm{I}_{2} \frac{1}{2}$ inches to 24 inches and even 64 inches (city and town surveys), the output, detailed partly in miles and partly in acres, was reckoned to be satisfactory. Every class of country was included in the field of work, from the sands of Rajputana to the dense forest-covered hill tracts of Burma, and we read of the time-old difficulties, heavy and continuous rain, malaria, and even of the clearance of villages by man-eating tigers. It is interesting to observe that the sources of the Irawadi (so long a geographical problem) were finally mapped.

Although the costs of the different classes and scales of survey are set out in considerable detail, it is difficult to frame any conclusion as to whether those costs have risen since the War. The normal one-inch scale of original survey apparently varied between $20 \mathrm{Rs}$. per square mile in Bengal and yo Rs. in Lower Burma. This does not indicate any great increase on pre-war costs, but in itself scarcely justifies any general estimate.

In the geodesic and scientific branch of the department there is a curtailment of activity. No firstclass triangulation was carried out, and both the

1 Records of the Survey of India : Annual report of Parties and Offices for I9I9-20, vol. I5. pendulum and latitude observations were suspended, but the registrations of tidal curves by means of self-registering tide-gauges were continued at Aden and at the principal ports of India. Levelling operations were also continued, and a new geodesic level net of India has been inaugurated on which levelling of high precision on the "fore and back" system will be the method employed. Like the exact determination of the height of the principal peaks of the Himalaya, it might be open to question whether the practical results of extreme precision are worth the expense of determination. The magnetic survey was also carried on during this season. The report closes with the usual returns of the computing- and drawing-offices.

The chief point of interest in the volume is found in Appendix II.- the report on the expedition to Kamet by Major Morshead, who afterwards took such an active part in the Everest expedition. Kamet $(25,445$ feet high) is the culminating peak of the Zaskar range, and afforded Major Morshead and that distinguished mountaineer, Dr. Kellas, an excellent opportunity for scientific observation on the effect of high altitudes on the human body. Appendix III. is also interesting, recording a note on the topography of the Nun Kun massif in Ladakh by Major Kenneth Mason. He has a good deal to say in criticism of Mrs. Bullock Workman's claim to have established the height and position of certain peaks of that group, in which she disagrees with Indian Survey results. It is always dangerous for the amateur to claim greater accuracy than that maintained by the Trigonometrical Survey of India. Mrs. Bullock Workman, in publishing her account of her extraordinary feats of climbing, pits herself against the G.T.S. and suffers accordingly.

T. H. H.

\section{Polish Celebrations of the 450th Anniversary of the Birth of Copernicus.}

NICOLAUS COPERNICUS was born on February 19, 1473, in Toruń (Thorn), a town situated on the Vistula, in the north-west of Poland; the 45oth anniversary of the birthday of the great astronomer occurred thus on Monday, February 19, and was celebrated in many parts of Poland with much solemnity. Impressive ceremonies were held in Warsaw, Wilno, Poznań, Lódź, Wloclawek, and Kieke ; in the Jagellonian University of Cracow (where for four years, I49I-I495, Copernicus was an undergraduate) the celebrations in commemoration of the anniversary will be held at a later date, probably in May.

In connexion with the Cracow proceedings a work, "Stromata Copernicana," will be published under the auspices of the Polish Academy of Sciences and Letters in Cracow; its author is Prof. L. Birkenmajer, the well-known biographer of Copernicus. We have not the space to enter into an account of Prof. Birkenmajer's investigations, but the following interesting fact may be mentioned : On the October page for the year I505 of the book "Calendarium Magistri Joannis de Monte Regio," preserved in the Uppsala University Library (sign. "Incunab." 840), Prof. Birkenmajer discovered, in Copernicus's wellknown handwriting, the Polish inscription (twice repeated) "Bok pomagay" (Our Lord, help us). Writing on this interesting detail, Prof. Jan Loś, the well-known philologist (and professor of the history of Polish language in the Jagellonian University of Cracow), says: "In the year I 505 every Pole would have written the words given above exactly in the form in which Copernicus has written them " (Jezyk Polski, vol. viii., No. I). Prof. Birkenmajer adds that in 1505 , or perhaps in 1506 , Copernicus had already in his mind the ideas which eventually took form in the well-known revolutionary " Commentariolus."

The Copernicus commemoration at Toruń extended over the two days-February $\mathrm{r} 8$ and I9; delegates from all the universities, bigh schools, scientific societies, etc., of Poland, and other guests were cordially received by the municipality and citizens of Torun. The proceedings included the inauguration of the first general meeting of the Polish Astronomical Society. This meeting resolved unanimously to ask the Polish nation to establish a National Astronomical Institute in Poland; an attempt with this object in view was made by Prof. Banachiewicz, of the Jagellonian University of Cracow, and exists in the form of an astronomical station in the Carpathian Mountains. A memorial tablet on the house where Copernicus was born was also unveiled. 